\title{
Las Injusticias sociales en la prensa masónica de fines del siglo XIX: El Boletín de Procedimientos del Gran Oriente Ibérico
}

\author{
Eduardo Enríquez del Árbol \\ Historiador, Universidad de Granada, España. Miembro de la Junta Directiva del Centro de Estudios \\ Históricos de la Masonería Española (CEHME). \\ Correo electrónico: darboleduard@gmail.com
}

Fecha de recibido: 30 de enero de 2015 - Fecha de aceptación: 20 de febrero de 2015

Palabras claves

Gran Oriente Ibérico, España, cuestión social, injusticia social, siglo XIX

Keywords

Iberian Grant Orient, Spain, social question, social injustice, $19^{\text {th }}$ century

\section{Resumen}

Esta comunicación tiene la pretensión, sin ánimo exhaustivo, de sopesar la preocupación de la masonería decimonónica sobre los males de la sociedad española. Es decir, el gran problema social entre la España real y la España oficial. Sobre la cuestión social, con la excepción del Gran Oriente Español, ningún alto organismo de la masonería en el siglo XIX, dedicó una atención prioritaria como el Gran Oriente Ibérico, quizás el más "politizado" de todos ellos. Por lo tanto, este trabajo discute los textos más importantes sobre las injusticias sociales de su Boletín de Procedimiento durante 1890.

\begin{abstract}
This communication analyzed the concerns of nineteenth-century Freemasonry regarding the ills of Spanish society. That is, the great social conflict between the real Spain and the official Spain. On the social question, with the exception of the Grand Orient of Spain, no senior body of Freemasonry in the nineteenth century commanded as much attention as the Iberian Grant Orient, perhaps the most "politicized" of them all. Therefore, this work discusses the most important texts on social injustices in its Bulletin of Procedure during 1890.
\end{abstract}

\section{Introducción}

Esta modesta comunicación tiene la pretensión, sin ánimo exhaustivo, de poner de relieve la preocupación que suscitaba en un caso concreto de la Institución masónica los males de la sociedad española a fines del siglo XIX. Nos referimos especialmente al gran problema social, que enfrentaba la España real a la España oficial y cuando en los últimos tiempos se percibe un interés creciente por los estudios de los fenómenos de transmisión de ideología y de creación de mentalidad. Queremos presentar, pues, un análisis sobre las líneas de pensamiento que enmarcan un grupo de élite masónico sobre una de las cuestiones acuciantes en que se debatía la sociedad española, en el momento en que las cuestión social y que la revista masónica llamará con más acierto, injusticias sociales, 
estaba desplazando a cualquier otro problema grave de la sociedad y que ocupará desde ahora un protagonismo que no abandonará en todo el periodo posterior ${ }^{1}$. No hay que olvidar que la Masonería sirvió en los países católicos para canalizar ideas progresistas junto con los deseos de regeneración mediante un camino de perfección en la búsqueda y realización de la libertad, la igualdad y la fraternidad masónicas ${ }^{2}$.

Resulta ineludible hacer referencia a una previa visión de conjunto en que se desarrolla el problema social aunque es evidente que tratar de explicar en pocas líneas la crisis finisecular que azota al país en el periodo de la Regencia de María Cristina, es una tarea imposible por la cantidad de factores y variables que inciden en los acontecimientos. En cuanto a las causas profundas, en una primera ojeada debemos situarla en el contexto internacional de un ciclo de sobreproducción y redistribución del sistema capitalista que había alcanzado ya dimensión internacional. Basta con enumerar los siguientes datos: Se produjo una crisis agraria, con el aumento de la importación de cereales, el descenso de los precios y la bajada de la producción. Se afectaron principalmente los que Vivian del campo, es decir más del $60 \%$ de la población que comprendía a los terratenientes, y en mucho mayor número, a pequeños labradores, a colonos y jornaleros. En una estructura económica de este signo, este cambio incidió también en las pequeñas industrias y el trabajo artesanal o menestral. Se arruinaron los pequeños propietarios forzándolos junto a los braceros a la emigración ${ }^{3}$. Unese a ello, el aumento de la población que alcanzará los 18 millones de habitantes, el déficit fiscal originado por un ineficaz régimen tributario, la escasa industrialización, el crecimiento de las aglomeraciones urbanas, los doce millones de analfabetos, la gran mendicidad, etc. Todo aboca a una grave crisis social que golpea a todas las clases, sobre todo a las más desfavorecidas ${ }^{4}$. La respuesta de los países subdesarrollados y vinculados en mayor medida al sector primario, fue aplicar, entre otras medidas, los aranceles proteccionistas.

Añadamos en esta breve reseña, la imposibilidad de avance en un régimen político bipartidista de oligarquía y caciquismo, el rechazo de las masas desmoralizadas y el azaroso discurrir de un catolicismo confundido.

Aunque el cambio para un mundo más justo y fraternal como acabamos de señalar, constituía de suyo una de las esencias de la Masonería latina, sin embargo, sobre la cuestión social con la excepción del Gran Oriente Español, ningún alto organismo de la

\footnotetext{
${ }^{1}$ Ya entonces fueron numerosos los estudios, informes, discursos y artículos acerca de esta problemática, que se agudiza a partir de 1885 y que encontramos en todos los periódicos liberales, conservadores y republicanos, amén de los socialistas. La producción es ingente a partir de primeros del siglo XX a través del Instituto de Reformas Sociales.

${ }^{2}$ Describía hace años Tuñón de Lara el fenómeno: "Lo social anunciado vagamente puede ser una novedad a fines del siglo XIX; no se trata empero, de ciencia social, sino de una simple intencionalidad hacia el objeto de conocimiento y, en ocasiones, de juicio moral" (Tuñon de LARA, M., Medio siglo de cultura española (Madrid: Tecnos, 1970), 98.

${ }^{3}$ Facilitada por la concesión, en 1873, de la libertad de emigrar. Se calcula entre 1882 y 1914 salieron más de dos millones hacia Cuba y América Latina y un millón a Francia, Italia y Argelia.

${ }^{4}$ En realidad se dan la mano diversas crisis: económica (agraria e industrial), social, política, cultural, educacional, etc. que se repiten en los parámetros capitalistas.
} 
Institución en el siglo XIX, dedicó una atención prioritaria como el Gran Oriente Ibérico, quizás por ser el más "politizado" de todos ellos 5 .

A este Gran Oriente Ibérico o Gran Logia Simbólica Española del Rito Primitivo y Oriental de Memphis y Mizraím (1889-1898), del que su única documentación es su denominado Boletín de Procedimientos, le dedicamos hace ya muchos años, un artículo muy sintetizado que por la brevedad impuesta no pudimos desarrollar en todo su contenido ${ }^{6}$.

Nuestro empeño en estos párrafos que siguen es llevar a cabo un análisis ideológico recurriendo a los textos más importantes de este órgano oficial sobre las injusticias sociales que se vierten en 1890, poniendo de manifiesto su mirada desaprobadora de la situación social y los posibles remedios, que la cúpula rectora del Oriente transmitió a sus lectores.

Para una comprensión de los antecedentes antes de entrar en materia, exponemos a continuación una sucinta síntesis del Gran Oriente y de su órgano oficial, el Boletín de Procedimientos.

Pasamos seguidamente al estudio de las Injusticias sociales en las páginas del Boletín, así como a las Ideas-clave del discurso masónico y, por último, a las Conclusiones.

\section{La nueva obediencia y su Boletín de Procedimientos}

\section{La fundación dela Obediencia: Sus principios y fines}

La fundación fue llevada a cabo por un grupo de masones españoles que pertenecían a la alta, media y pequeña burguesía ${ }^{7}$. Este nuevo Oriente que se constituía con un simbolismo independiente de la difundida Masonería del Rito Escocés Antiguo y Aceptado, tuvo lugar

\footnotetext{
5 "El B. de Procedimientos era la otra publicación masónica que, de forma teórica, hacía suyo el problema social, pero con una óptica más agresiva y progresista, hasta el extremo de justificar la injerencia del colectivo masónico en los temas profanos" (Fernández Fernández, Pedro Víctor, "La cuestión social en las publicaciones masónicas españolas", en Masonería española entre Europa y América, Ferrer Benimeli, José Antonio coord. (Gobierno de Aragón: Zaragoza, 1995), Tomo II, 615-616. El primer estudio pionero sobre una visión general de las Masonería y la cuestión social fue el de Ferrer Benimeli, "La Masonería española y la cuestión social", Estudios de Historia Social 40-41 (1987): 7-47. Corroborando esta escasez del tema en la Masonería: "En muy contadas ocasiones los organismos masónicos como tales se ocuparon de la "cuestión social" (...), en Ortiz Villalba, J., "Masonería y cuestión social en la Córdoba del último tercio del siglo XIX", en La Masonería en la España del siglo XIX, Ferrer Benimeli coord. (Valladolid: Junta de Castilla y León, 1987), tomo II, 740. En cuanto al pensamiento social de algunas logias del otro Gran Oriente hispano en esa época, véase Sanllorente Barragan, F., "Anticlericalismo, pacifismo y cuestión social en las logias del Gran Oriente Español", en La Masonería española y la crisis del 98, Ferrer Benimeli coord. (Zaragoza: CEHME, 1999), tomo I, 223-245.

${ }^{6}$ Véase para una breve historia de este Gran Oriente, Enríquez del Árbol, E, "Al filo de un centenario: El último Gran Oriente Hispano del siglo XIX: la Gran Logia Simbólica Española del Rito Primitivo y Oriental de Memphis y Mizraim (1889-1989)", en Masonería, Revolución y Reacción, Ferrer Benimeli coord. (Alicante: Diputación Provincial, Instituto Gil Albert, 1990), Tomo II, 989-1018. En él repasamos muy someramente sus relaciones con el fenómeno religioso, su ferviente republicanismo y el visceral anticlericalismo, la incorporación de la mujer a las logias, etc.

${ }^{7}$ Enríquez del Árbol, “Al filo de un centenario”, 996-1000.
} 
el 15 de febrero de 1887 meses antes de que se promulgara la Ley de Asociaciones bajo el gobierno de Sagasta, del 30 de junio del mismo año.

La nueva Obediencia desde el escocismo buscó un nuevo Rito considerado el más antiguo después de la fundación de la Gran Logia de Inglaterra, el llamado antiguo de Memphis y Mizraim de 96 y 90 grados respectivamente, que había sido creado al parecer en Nápoles el 10 de diciembre de $1747^{8}$. Este Rito sería sustituido después por la reforma hecha por el general Garibaldi, quien refundiendo los dos Ritos constituyó el Rito Antiguo Primitivo y Oriental, compuesto de 33 grados equiparados a los anteriores 9 .

Finalmente, el reconocimiento legal advino el 10 de enero de 1889, siendo aprobada la Constitución, compuesta de 56 artículos el $1^{\circ}$ de marzo del mismo año. Se convertían en los representantes únicos del "orientalismo" en España.

Una especie de memorándum que el Soberano Gran Consejo General Ibérico presentó en el primer número del recién creado Boletín de Procedimientos, de 5 de octubre, nos introduce en sus aspiraciones como Gran Oriente ${ }^{10} \mathrm{y}$ en cuanto a sus propósitos los sintetizamos en la puntos siguientes: Práctica de la Fraternidad verdadera; Amor a la Patria cuyo lema a seguir sería Patria, Progreso y Civilización; Amor a la Humanidad y formar una masonería fuerte, poderosa, práctica y verdadera ${ }^{11}$.

Este Oriente presentó la particularidad desde el principio al fundar una Gran Logia de Adopción de la clase obrera, exponente de la preocupación que mantuvo para la regeneración del trabajador manual. Otra característica a destacar es su transparencia en cuanto a la identidad de sus asociados ${ }^{12}$.

En el contexto político, al terminar el periodo liberal sagastino que tantas reformas había llevado a cabo bajo la Regencia (1886-1890), sube al poder Cánovas en 1890, partidario del proteccionismo. Bajo su mandato y el de Sagasta, después, se desarrollará el nuevo Gran Oriente.

\section{La creación del Boletín de Procedimientos como órgano oficial}

Uno de los fundadores de la Obediencia, Isidro Villarino del Villar, Gran Secretario, sabiendo la importancia de contar con una publicación que representara los ideales e intereses del Oriente y a la par un medio de comunicación con sus asociados, creó el

\footnotetext{
${ }^{8}$ Como en casi todos los Ritos de la Masonería predomina la obscuridad y confusión de sus orígenes. Una nueva versión nos dice que a principios del siglo XIX, en 1805, apareció el Rito de Mizraim o Judaico en Italia mientras que el de Memphis lo haría poco más tarde en Francia, en 1839. Véase L. Frau y R. Arus, Diccionario Enciclopédico de la Masonería (México D.F., 1976), Tomo III, 1486-1489.

${ }^{9} \mathrm{Su}$ Constitución se promulgó en Sebeto (Nápoles) el 30 de mayo de 1883 por el Imperial Supremo Consejo General dirigido por su Gran Maestre y Gran Jerofante del Rito, Juan Bautista Pessina.

${ }^{10}$ Que serían por este orden: Poner fin a la confusión y división de la Masonería española; Rechazo de la irregularidad de la Institución hispana y la elección de un Rito originario de la Masonería primitiva en una posición legal frente a las otras

Obediencias.

${ }^{11}$ Enríquez del Árbol, “Al filo de un centenario”, 994.

${ }^{12}$ Las disposiciones de que cualquier escrito debía firmarse además de con el nombre simbólico con el verdadero "profano" y no darse a la publicidad, siendo considerado clandestino cualquier escrito que estuviese firmado sólo por el simbólico Boletín de Procedimientos, desde ahora en adelante (B.P. II, no. 1 (1890): 32).
} 
llamado Boletín de Procedimientos de tirada quincenal, del Soberano Gran Consejo General Ibérico, que aparecerá en octubre de 1889 y terminará su singladura en $1898^{13}$.

En un principio expresaron las intenciones que animaban la publicación las sintetizamos así: Sus artículos habían de estar en función de los intereses y fines de la Asociación; No se permitirían luchas ni discusiones inútiles; Se deseaba que todos los asociados conocieran sus deberes y supieran el estado y condiciones que fueran adquiriendo.

La importancia de esta prensa, como hemos mencionado en otra ocasión, "va más allá de la mera información que nos sirve para verificar un fenómeno puntual, ya que como toda prensa, establece al mismo tiempo un mundo de representaciones y de comunicación creadora" $" 14$.

Como toda prensa masónica claramente ideológica, sirvió además para dar a conocer los proyectos o trabajos masónicos o profanos a condición de que no desdijeran de la Institución. Trabajos que servirían para mejorar las condiciones sociales de la Humanidad en todas las manifestaciones y necesidades de la vida y "cuanto pudiera servir de beneficio e instrucción a las clases trabajadoras" $"$.

\section{Las injusticias sociales en las páginas del Boletín}

\section{Introducción}

En la Introducción inicial mencionamos en síntesis el origen de la cuestión social que se percibía en la vida cotidiana como una mayoría de la población en un estado lamentable de miseria, de pobreza y de mendicidad, unida a otras connotaciones como su incultura, falta de higiene, viviendas insalubres, etc. Era la diagnosis de un país subdesarrollado con una diferencia desproporcionada entre las clases dirigentes y el pueblo representado por la clase baja e indigente. La crisis percibida desde 1885, se agudizó a partir de 1890 y alarmó a las fuerzas reaccionarias en el poder tanto a las españolas como a las europeas ${ }^{16}$.

\footnotetext{
${ }^{13}$ Su sede sería la misma de la Sociedad: El Centro de Coalición Republicana, en Carrera de San Jerónimo, 28, principal izquierda. La correspondencia debía dirigirse a Villarino, calle Leganitos, 18.

${ }^{14}$ Tras especificar lo que entendemos por prensa masónica, abundábamos en sus caracteres: "La carencia de una proyección pública abierta a todos y no siendo en ella un objetivo primordial el hacer demandas al sistema político de la sociedad, que caracteriza en general a la prensa". Por otra parte "ofrecía una mediación social reducida ya que se vincula a grupos minoritarios de la sociedad", etc. Véase Enríquez del Árbol, "La prensa masónica en la Andalucía del siglo XIX: Sus orígenes sevillanos: La Fraternidad y El Ramo de Acacia (1870-1873)", en Andalucía Contemporánea III (1996): 37-46. A la prensa le he dedicado atención desde hace mucho tiempo: Enríquez del Árbol, La cuestión romana en el diario madrileño El Pensamiento Español de 1870 (Madrid: Fundación Universitaria Española, 1987). También entre otras: "Reflexiones sobre Metodología para un estudio de la prensa", Anuario de Historia Contemporánea 8 (1981): 249-262; "La prensa masónica en la Andalucía del siglo XIX: Una aproximación a los orígenes gaditanos", Trocadero 3 (1991): 185-197.

${ }^{15}$ Con ello mostraba el objetivo intrínseco a la Obediencia: El servicio a las mencionadas clases Enríquez del Árbol, “Al filo de un centenario", 1004.

${ }^{16}$ En España tuvieron transcendencia entre otras, la Ley del sufragio universal de marzo de 1890 que quedaría falseada constantemente y la celebración de la Gran manifestación obrera del $1^{\circ}$ de mayo. En Europa, la larga huelga obrera del puerto de Londres de 1889 y la entrada en el Parlamento alemán del partido socialista con el $20 \%$ de los votos en 1890 y como consecuencia el Emperador Guillermo II convocó un Congreso
} 
En efecto, este magno problema como fue llamado por el Alto Cuerpo masónico, preocupó a los masones españoles, ya que la Institución tenía que verse implicada en la cuestión si deseaba la regeneración social que propugnaba en su Ideario y que se traducía en la frase "mejorar las condiciones de la Humanidad"17.

Antes que nada veamos el alcance que le daban a este problema social los masones del Boletín:

Una de las diversas y múltiples fases que presenta la sociedad del modo y forma en que se halla constituida, es lo que ha dado en llamarse la cuestión social, que tiene un alcance mucho mayor y de extraordinaria importancia y que no puede limitarse, como quieren y pretenden los anarquistas y los socialistas, a sus luchas con los patronos, a que predomine el capital sobre el obrero o a que éste haga sucumbir al capitalista ${ }^{18}$.

Por otra parte, se indicaba con claridad meridiana cual era el método a seguir, método diríamos académico, aunque después no lo pusieran en práctica:

(...) para estudiar cualquier fenómeno, para examinar un estado cualquiera y para formar una idea exacta y acabada de lo que había de ser objeto de la investigación, es necesario estudiar el fenómeno, examinarle y verle en sí mismo, antes que de estudiar, examinar y ver lo que con ese fenómeno se relacione. Para estudiar las injusticias en cada una de las clases sociales, era indispensable estudiar la organización interior de cada clase y que se vieran todas las deficiencias que existieran (...). Descubrir esas arbitrariedades, esas injusticias, era dar a conocer el remedio ${ }^{19}$.

Nos hemos centrado, en las páginas que siguen, en los artículos del Boletín de Procedimientos acotado en el año en que más se ocupó del problema, el año 1890. Del análisis de los textos se infiere que son de tipo ideológico donde predomina un aspecto argumentativo y persiguen un fin persuasivo interpelando al adversario y a veces con fuerte estructura retórica ${ }^{20}$.

\section{Los artículos bajo el membrete de "Injusticias sociales"}

Bajo este epígrafe y conscientes del espacio disponible, vamos a analizar los ocho los trabajos y que abarcan desde marzo a julio de $1890^{21}$. Con ello ofrecemos una visión suficiente de la cuestión tratada en estos primeros números del Boletín. No siempre siguen

\footnotetext{
internacional.

${ }^{17}$ Concebida sin embargo, por la Masonería regular como una acción individual.

${ }^{18}$ B.P. II, no. 10 (1890): "Injusticias sociales (VI)", 10-11.

${ }^{19}$ B.P. II, no. 6 (1890): "Injusticias sociales (II)", 10.

${ }^{20}$ Por cuestión de espacio hemos dejado para otro estudio la visión que este Gran Oriente tenía sobre el mundo obrero.

${ }^{21}$ A fines de 1891 aparecieron cuatro artículos con el título "Defectos del sistema de educación actual" firmados por un masón que tenía por simbólico Etnófilo $1^{\circ}$. Es toda una sátira de la educación del niño imaginando escenas pormenorizadas de escaso valor testimonial.
} 
un orden en la exposición de su pensamiento, que a veces se repite mezclado con la literatura periodística al uso y con otras consideraciones de menos interés. En consecuencia, hemos extraído los párrafos más importantes del discurso, ordenándolos conforme a las ideas principales que sustentan encuadrándolos en las entradas múltiples que hemos considerado.

Me he permitido transcribir algunos textos originales, los más significativos, con el objetivo de acortar distancias del escrito con el lector y que éste aprecie de visu las expresiones utilizadas y el nivel argumental junto a la carga emocional que encierran muy acorde con el estilo de la prensa de la época.

En el primer artículo de mediados de marzo expuso la situación de las clases más desfavorecida $^{22}$, al mismo tiempo que consideraba necesario tener presente las condiciones de vida de las distintas clases, "no para que sirviera de enseñanza, que era de todos bien sabido sino de recuerdo constante, de aguijón que estimulara y llevara a todos al cumplimiento de los sagrados e ineludibles deberes"23.

\section{El nudo de la cuestión: La educación}

Pasaba el texto a examinar la causa de todos los males y la hallaba en la perniciosa y deficiente educación. Esta debía tener unos principios básicos: 1) El culto a la razón. 2) Que no existiera imposición alguna sobre la conciencia humana, cesando la esclavitud que pesaba sobre ella ${ }^{24}$.

Desconfiaba de la educación que el niño recibía que venía dada por la mujer, la cual por la educación recibida era la menos apropiada para realizar esas funciones tan importantes de la vida, porque estaba llena de preocupaciones e impregnada de fanatismo. Era una educación viciosa y lo era mucho más deficiente en su parte material puesto que en este punto del desarrollo físico era aun mayor su ignorancia. Al raquitismo físico podía ir acompañado de la falta de los más estrictos principios de moralidad ${ }^{25}$ y surgía un ser humano raquítico y deficiente; un ser humano que casi siempre guiaba y dirigía sus primeros pasos "en grosero materialismo, acompañado de un sensual positivismo, que es más grosero y más raquítico que aquél (...)"26.

\section{Las pasiones, el deber y su importancia en la educación}

Siguiendo con el desarrollo del niño aseveraba que de esas preocupaciones que en la primera edad se adquirían nacían errores difíciles de destruir después, originándose pasiones que venían a determinar el bien o malestar de cada hombre durante esta vida.

\footnotetext{
22 "Si examinamos la sociedad en sus cuerpos inferiores en donde se encuentran los que sufren, los que viven una existencia en continuo llanto, amargo y triste, allí encontraremos entronizados la injusticia, enseñoreándose la misma, aumentada por inmensas penalidades de las que no es menor la carencia absoluta de apoyo y el desconocimiento completo de la estricta justicia (...)”. B.P. II, no. 5 (1890), "Injusticias sociales (I)", 5-6.

${ }^{23}$ B.P. II, no. 5 (1890), "Injusticias sociales (I)", 6.

${ }^{24}$ B.P. II, no. 11 (1890), "Injusticias sociales (VIII)", 8-10.

${ }^{25}$ B.P. II, no. 11 (1890), "Injusticias sociales (VIII)", 8-10.

${ }^{26}$ B.P. II, no. 6 (1890), "Injusticias sociales (II)", 9.
} 
A continuación pasaban a un estudio psicológico de los sentimientos y la pasión ${ }^{27}$.

Las pasiones verdaderas, las activas, cuentan en primer lugar con el amor. Los tres estadios del niño -escribían- eran el sentir su debilidad, el pasar a la admiración y el paso a la gratitud.

Pero la pasión era buena en el hombre, necesaria y útil ${ }^{28}$.

Del mismo modo estudiaba el deber que era lo que la ley de la naturaleza había propuesto al ser humano desde el primer instante de su existencia, que bajo el sentido común era toda obligación impuesta al hombre. Aunque había diferentes apreciaciones, no llegó a definirlo con claridad ${ }^{29}$ y ponía ejemplos comentando la obra de Víctor Hugo, Los miserables, en las condiciones y conductas de sus protagonistas. Aplicaba el concepto distinto de la pasión y del deber en que se mezclaban las posturas inflexibles con la ley fundada en la caridad ${ }^{30}$.

La pasión y el deber eran los signos opuestos. "El ser infinito que formó al hombre ordenó los sucesos que forman su vida de modo que la pasión no existiera sino mucho después de existir el uso de razón".

Al final de todo lo expuesto en un razonamiento escalonado defendería: $1^{\circ}$ No la pasión que convierte al hombre en bestia, pero sí la pasión que abriga ilusión; $2^{\circ}$ ) Entre el deber impuesto por los hombres y el deber impuesto por la ley natural optaba por el segundo; $3^{\circ}$ ) La compasión hacía pasar al hombre de la pasión al deber ${ }^{31}$.

A mayor abundamiento, fundamentaría el estado del hombre bajo las leyes de la naturaleza que eran inmutables, eternas y universales en las que todo obedecía a ciertas condiciones tanto en el mundo del universo como en el mundo vegetal o animal. Y esto también se aplicaba al nacimiento, conservación y desarrollo de las sociedades humanas ${ }^{32}$. Advertía a los presentes que no debían formar juicios anticipados en historia, moral, psicología, política, como ocurría con los pensadores del siglo XVII. Esta manera de pensar se rechazó en el siglo XVIII, argumentando siempre desde la observación, nunca desde la revelación ${ }^{33}$.

\footnotetext{
${ }^{27}$ Distinguían la pasión activa, que es la que hace padecer o sufrir (amor, odio, cólera, venganza) y que se determina en nosotros por ese movimiento interior que tiene su origen en el sentimiento adornado por la fantasía, con el que llevaba al hombre, como si careciese del uso de libre albedrío que le enaltece, de la libertad que le distingue y de la responsabilidad que como ser libre tiene, hacia la cosa o persona que excitó tal sentimiento (...). Mientras que la pasión pasiva o deprimente se hallaba antes que el individuo tuviera uso de razón, en el niño por ejemplo.

28 "Es buena porque le saca de la condición de las bestias y le lleva a buscar un ideal; es necesaria porque le estimula en su carrera y es útil porque le hace conocer la mejor de sus facultades la que le hace a imagen y semejanza del ser supremo, la que le imputa responsabilidad de todas sus acciones, la libertad, en fin (...)". B.P. II, no. 7 (1890), "Injusticias sociales (III)", 3-5.

${ }^{29}$ B.P. II, no. 7 (1890), "Injusticias sociales (III)", 5.

${ }^{30}$ B.P. II, no. 8 (1890), "Injusticias sociales (IV)", 4-5.

${ }^{31}$ B.P. II, no. 8 (1890), "Injusticias sociales (IV)", 5.

${ }^{32}$ Igualmente aplicado al hombre, con la formación, lucha, desarrollo y dirección de las ideas, de los pensamientos, de las pasiones y de los juicios y voluntades del individuo. recordaba a Voltaire para quien todos los seres sin excepción alguna estaban sometidos a leyes inmutables (Del principio de acción) en B.P. II, no. 9 (1890), "Injusticias sociales (V)", 20-21.

${ }^{33}$ B.P. II, no. 9 (1890), "Injusticias sociales (V)", 21.
} 


\section{La protección legal de los menores. La ley de julio de 1873}

Al socaire de este clima, en el mismo texto traía a colación un artículo de El Liberal que a su vez alababa al periódico conservador El Estandarte, que había dado un golpe de oportunidad exhumando la ley de 24 de julio de 1873. Ley no derogada que daba satisfacción al deseo de protección legal a los niños, pero como si no existiese, los que

(...) se llaman directores de los intereses de las clases trabajadoras piden protección para niños y niñas, cuando no hay más que reclamar el cumplimiento de la ley vigente. El Estado interpuso la protección para los jóvenes hasta los quince años y para las jóvenes hasta los diecisiete ${ }^{34}$.

Siguiendo su posición respecto a la intervención estatal, se preguntaba el Boletín por qué había quedado esta ley como letra muerta. Simplemente porque las cuestiones que tocaba no podían ser resueltas por disposiciones legales y "porque el Estado pretenderá siempre estérilmente sustituir al padre y a la familia en las funciones que son propias de la esfera individual" 35 .

\section{El origen de las injusticias: Ignorancia y fanatismo}

Se proponía examinar el estado social y deducir de su estudio el origen y causas de donde procedían todas las injusticias, de las que eran víctimas todas las clases sociales. Aunque dependían de distintas causas con orígenes diferentes, procedían de la deficiencia y cuyo origen -repetía- estaba en la perniciosa y cuanto deficiente educación ${ }^{36}$.

Las injusticias sociales obedecían, pues, al estado de ignorancia y al fanatismo que de ésta nacía. Si bien la ignorancia existía en todas las clases, era más grande aún en la clase obrera y en consecuencia, el medio para remediar esos males no podía ser otro que adquirir la instrucción lo más extensa posible y hacer desaparecer la ignorancia, germen, origen y fundamento de esos inmensos males:

Con ilustración no permitirán nuestros obreros la explotación de que vienen siendo objeto por las clases acomodadas, que a su vez carecen de la ilustración necesaria en el ser humano para no convertir a sus semejantes en instrumentos ciegos e inconscientes de su ambición, convirtiéndolos en máquinas y haciendo que sus esfuerzos resulten estériles, no solamente para ellos, sino que también no son todos los fructíferos que debían ser para aquellos que tratan de explotarlos ${ }^{37}$.

Comprenderían lo mismo las clases obreras que los patronos, explotadores de aquéllas, que era de interés suyo dedicar su esfuerzo y toda su actividad "a aumentar la

\footnotetext{
${ }^{34}$ La ley prohibía el trabajo de los niños y las niñas menores de diez años en las fábricas, taller, fundición o mina; que excediera de cinco horas el trabajo de los niños menores de trece años y el de las niñas menores de catorce y que trabajaran de noche los jóvenes menores de quince años y las jóvenes menores de diecisiete.

${ }^{35}$ B.P. II, no. 9 (1890), "Las manifestaciones de los obreros", 11.

${ }^{36}$ B.P. II, no. 5 (1890), "Injusticias sociales (I)", 8.

${ }^{37}$ B.P. II, no. 13 (1890), "Injusticias sociales (VII)", 4-5.
} 
riqueza de los que les proporcionaban trabajo para atender con el producto de su salario a sus necesidades" ${ }^{38}$.

\section{La necesidad de asociarse}

Cultivando el obrero su inteligencia, adquiriría el hábito de asociación y unidos todos podrían obtener con mayor facilidad todo aquello que no obtenían por falta de unión y hasta por el desconocimiento de sus necesidades. Los obreros de un solo oficio debían fundar asociaciones que se dedicaran a estudiar las necesidades procurando su instrucción y la de los suyos. Después se ampliaría a todos los obreros de las industrias, estableciendo verdaderas federaciones que establecerían una verdadera resistencia contra las pretensiones del capital que resultasen injustas.

Las reclamaciones serían útiles y beneficiosas cuando todos los esfuerzos se dirigieran con inteligencia por todos los obreros asociados y con la ilustración adquirida en los centros sociales que ellos mismos fundasen ${ }^{39}$.

Sin más argumentos admitía que los fabricantes tendrían que someterse a sus reclamaciones y tendrían necesidad de plegarse a sus pretensiones cediendo a favor de sus trabajadores parte de sus ganancias ${ }^{40}$. El obrero satisfechas sus necesidades haría esfuerzos por mejorar su calidad y en el tiempo.

Como ya había expresado en otras ocasiones, pretender que el Estado impusiese por la fuerza a uno sobre el otro era una insensatez. Y pedía que los estudiaran bien nuestros obreros y lo meditaran los fabricantes y "seguro que cesarán muchas de las injusticias de que se lamentan todos los hombres honrados y unos y otros conseguirán el fruto de su trabajo, de su desvelo y el producto natural que debe tener también el capital"41.

\section{El camino equivocado: EI desorden y la agitación social}

Era justo que los obreros intentasen salir del estado en que se hallaban, pero para el autor estaban adoptando un camino de ruina y un malestar mucho mayores de lo que experimentaban ${ }^{42}$. Era necesario que el obrero comprendiese por medio de una sólida instrucción sus verdaderos intereses. Se estaba en contra de las utopías que los partidos extremos propugnaban, culpándolos de la conducta miserable del obrero:

\footnotetext{
38 "Y a su mejoramiento en todos los órdenes de la vida y los patronos verían que era para ellos más útil y más conveniente el conservar el trabajo sin hacerlo objeto de sórdida explotación puesto que siéndole aquellos de necesidad continua, estaba en su interés que permanecieran prestándoles sus servicios el mayor tiempo posible siendo conocedores de lo que tenían que hacer". B.P. II, no. 13 (1890), "Injusticias sociales (VII)", 5.

39 Terminaba recomendando: "Piensen en esto nuestras clases obreras, organicen esas vastas asociaciones que se encuentran fundadas en países liberales y democráticos, y que las fructíferas son para el desarrollo moral e intelectual del hombre, habrán conseguido con esto, que si se desaparecen del todo, sean al menos, menores las INJUSTICIAS SOCIALES de que hoy vienen siendo víctimas, y de las que todos nos lamentamos diariamente". B.P. II, no. 13 (1890), "Injusticias sociales (VII)", 5.

${ }^{40}$ B.P. II, no. 14 (1890), "Injusticias sociales (VIII)", 7-8.

${ }^{41}$ B.P. II, no. 14 (1890), "Injusticias sociales (VIII)", 8.

${ }^{42}$ Una vez más se oponía a que el Estado había de darles solución, "cuando los obreros venían siendo los instrumentos hasta cierto punto inconscientes de los eternos enemigos de los Gobiernos liberales".
} 
En tanto que se deje guiar e ilusione por promesas que jamás han realizado, que han resultado ilusorias y vanas y que encierran un fondo de egoísmo, que su falta de conocimiento de las cosas y de las personas les impide comprender, no obtendrá su regeneración, no conseguirá su mejoramiento y eternamente existirán esas INJUSTICIAS SOCIALES, de que venimos lamentándonos y que tiene su base, su fundamento y su origen en esa conducta censurable del obrero, que se produce de ese modo, porque ignora las malas artes de los que explotan su buena fe, la doblez y la mala intención que preside las acciones de los que por tan tortuosos caminos los conducen ${ }^{43}$.

Se referían a las algaradas que redundaban en perjuicio no sólo de las demás clases sociales que se veían lastimadas por esas perturbaciones sino de los mismos obreros. Acto seguido lanzaba una perorata esperanzadora: "Que servían para retroceder o cuando menos, paralizar la marcha del progreso, que caminaba a pasos agigantados a conseguir que los desheredados de todas las épocas consiguieran su emancipación”,44.

\section{Las ideas-clave del discurso masónico sobre las injusticias sociales}

Procedamos ahora a exponer las ideas-fuerza de la ideología sostenida en los textos manejados de contenido social y que reflejadas en el orden expositivo, serían las siguientes:

1. Crítica de la situación española. A través de los textos del Boletín aunque no hay una crítica explícita de los factores de la crisis social, asume desde una posición liberal o más bien desde el enfoque republicano-democrático, la descripción de la situación deplorable de las clases bajas de la población. Para el órgano masónico, la injusticia social estaba entronizada en las clases más desfavorecidas. Los testimonios aportados por el Boletín nos muestran su preocupación por la angustia y desesperación de una gran parte de la sociedad, en los "cuerpos inferiores" como los llama, que además se dilataba hasta comprender a todas las clases.

2. La perniciosa educación. Buscando el origen de las injusticias. Los masones del Boletín ponían su explicación en la educación del niño. Se aprecia un hecho básico: $\mathrm{Su}$ desconfianza en la primera educación que no debía darla su madre, por su ignorancia y fanatismo, toda vez que está presente no sólo el espíritu anticlerical que consideraba -muy frecuente en la Masonería de fines de siglo-que la mujer estaba dominada en el confesionario por la moral hipócrita del jesuitismo, sino también por la enseñanza roussoniana. Sin embargo, se queda en la desnuda crítica, pero no nos señala que podría hacerse ¿jardines de la infancia como preconizó Froedel?

Por otra parte, el discurso psicológico que nos ofrece el texto sobre pasiones y deberes es el que encontramos en los autores del momento aparte de los pedagogos

\footnotetext{
${ }^{43}$ B.P. II, no. (1890), "Injusticias sociales (VI)”, 10-11.

${ }^{44}$ B.P. II, no. (1890), "Injusticias sociales (VI)”, 11.
} 
Rousseau, Pestalozzi, Froeder traducidos al español a lo largo del siglo XIX. O en los hispanos ${ }^{45}$. Partidarios de la pasión activa que abrigaba ilusión y de la preferencia por el deber impuesto por la naturaleza, mediante las leyes inmutables y eternas ${ }^{46}$.

3. Hacia una educación laica sin la intervención del Estado. El Boletín aunque no lo afirme explícitamente a través del rechazo a una enseñanza religiosa preconiza una educación laica, natural y sin imposiciones. Era sin lugar a dudas, la base necesaria para el progreso de la persona al margen de cualquier educación religiosa a la que se tachaba de una pedagogía esclerotizante de la conciencia.

Sin embargo, en ningún momento habla de la labor extraordinaria que estaba haciendo la Institución Libre de Enseñanza. Se trasluce que debería estar de acuerdo con ésta, al comulgar con la ideología liberal-republicana ya que propugnaba una enseñanza armónica primaria y secundaria más de formación que de instrucción, aconfesional o neutral, pero no irreligiosa. Solo en este punto entraría en desacuerdo, al ser los masones del Boletín decididamente anticlericales ${ }^{47}$.

A fin de cuentas, como buenos liberales se oponen a la intervención del Estado en la educación, en la que no debía interferir dejándola en manos de los padres ${ }^{48}$. Lo demostraba en el arrumbamiento de la ley de protección del menor de 1873 vigente y de la que nadie se acordaba.

4. La ignorancia y el fanatismo causa de las injusticias sociales. Como consecuencia de esta mala educación que estaba presente en todas las clases sociales, derivaba la revista masónica los males sociales, es decir de la ignorancia y como corolario del fanatismo. Se insiste por doquier que el remedio era adquirir la instrucción lo más extensa posible tanto obreros como patronos. Instrucción que también debería extenderse a las demás capas sociales.

5. La necesidad de asociarse. Tras la instrucción, los obreros deberían tener la necesidad absoluta de asociarse frente a los patronos, para conseguir justicia, creando asociaciones y

\footnotetext{
${ }^{45}$ La influencia de Rousseau en el Emilio se extiende a todos los demás. Pedro Felipe Monlau, autor entre otras obras en la primera mitad del siglo Curso de Psicología y Lógica, en 1844 en la que hace un estudio de la sensibilidad, inteligencia y voluntad y Elementos de la psicología (1848); Urbano González Serrano que apela a la psicología para la renovación de la educación y de la pedagogía; el neokantiano José del Perojo en su Ensayo sobre educación (1886), o Bartolomé Cossío que desde la Institución Libre de Enseñanza, escribe sobre la escuela y sus problemas en la década de los ochenta en el Boletín de la misma. Así "El trabajo manual en la escuela primaria" de 1884, "Nombramientos de maestros en las escuelas" de 1890 y su obra $L a$ enseñanza primaria en España (Madrid: Forfanef, 1897), etc. Josep Figueras y Pey con su Elocuencia moral (Barcelona: Librería Mayol, 1890), para la $1^{\mathrm{a}}$ y $2^{\mathrm{a}}$ enseñanza, etc.

${ }^{46}$ Años más tarde se publicará un suelto, "Educación de la Mujer y la Masonería" escrito por un masón, Enrique Pérez, Hércules, gr. $30^{\circ}$, en el que hace un recorrido del abandono sufrido, instando a la Masonería a cubrir esa necesidad social como era la educación de la mujer. B.P. IV, no. 37 (1892): 5-7.

${ }^{47}$ Sobre la afinidad entre masonería y la Institución Libre de Enseñanza, véase R. Asin Vergara, "Relaciones e influencia entre la Masonería y la Institución Libre de Enseñanza: El caso de Rafael Altamira”, en $L a$ Masonería en la España del siglo XX, Ferrer Benimeli coord. (Toledo: Universidad Castilla la Mancha, 1996), Tomo I, 373-403.

${ }^{48}$ María Esther Aguirre, La escuela primaria (1780-1890) (Madrid: Utopía, 2012).
} 
federaciones de trabajadores de los distintos oficios. Estas sociedades transformadas en Sociedades de resistencia podían hacer frente al Capital para superar momentos de crisis, de paro o de huelgas.

6. El camino equivocado en la actuación. Advertía el Boletín que camino por el que no debía transitar el comportamiento obrero era el desorden y la agitación social. No debían dejarse guiar por promesas que jamás se llevarían a cabo y cuya conducta censurable era debida a ignorar las malas artes, la doblez y mala intención de los que explotaban su buena fe.

7. Equidistancia entre Capital y Trabajo. No hay la más mínima condena del Capital sino que desde una mente ilustrada era un componente inevitable de la sociedad. La directiva masónica se mantiene en una posición ambigua, que si por una parte sale en defensa de los débiles obreros, en general de las clases menesterosas, por otra parte no niegan el valor que tiene el Capital y el cual tiene que obtener su provecho.

Resulta obvio negar que hubiese acuerdo solo con las reclamaciones de los obreros ante los patronos por muy instruidos que aquéllos fuesen. De otro lado, destaquemos también que mientras al Estado no se le veía como un explotador, se le negaba la posibilidad a participar en esa lucha entre Capital y Trabajo.

\section{Conclusiones}

Conviene recordar que no hacemos un discurso unívoco de la Masonería española, sino de una Obediencia concreta, el Gran Oriente de Memphis y Mizraim y en una etapa determinada, sobre el tema que nos propusimos estudiar. La mayoría de las Obediencias españolas con Boletines a su cargo se preocuparán mucho más de los problemas internos de la organización y de su expansión que no de las cuestiones que aquejaban a la sociedad, al considerar la perfección del individuo como meta a cumplir para después expandir sus beneficios al resto de la población. Además en este caso que nos ocupa, la Institución habla como tal, es decir, su cúpula rectora y no a través de discursos de sus colaboradores que se asomaban a las páginas del Boletín.

No está de más añadir que faltan investigaciones que profundicen la ideología de esta élite social, que no de poder o política, que fueron las autoridades rectoras de la Masonería en el último tercio del siglo XIX $^{49}$.

En base a este discurso masónico abordando este tema de hondo calado social y que se construye desde posiciones de ideología liberal-republicana, notamos una gran pobreza intelectual dados los argumentos atendibles que se insertan en un programa de reformas superficiales al no ir acompañadas de cambios socio-económicos y en ausencia de una política social profunda. Si bien protestaban de la pedagogía que se practicaba que

\footnotetext{
${ }^{49}$ Sobre las ideología de estos altos organismos en torno al 98, véase mi artículo: “Crisis y belicismo: Una perspectiva ideológica de la Masonería española en torno al, 98", en La Masonería en la crisis colonial del 98, Ferrer Benimeli coord. (Zaragoza: Ministerio de Educación y Ciencia, 1999), Tomo II, 979-1007.
} 
era esclerotizante de la conciencia y que conducía irremediablemente a la superstición, al fanatismo y a la irracionalidad, es difícil aceptar la posición que los males de la sociedad tenían su remedio solo en la educación por muy importante que fuera ésta.

Por otra parte hay un silencio revelador sobre aspectos de la educación del niño como la muy extendida percepción de injusticia con los maestros de escuela que vivían en condiciones semejantes al proletariado ${ }^{50}$. Al mismo tiempo notamos otros silencios o carencias en el discurso masónico sobre una problemática que cada vez se hace más variada y compleja dentro de las dificultades contextuales del sistema educativo ${ }^{51}$. No se menciona a la Comisión de Reformas Sociales de 1884 que abrió el conocimiento de la realidad a pie de campo y que sería la base para la creación del Instituto de Reformas Sociales en el siglo $\mathrm{XX}^{52}$. Silencio también en el sentido de la urbanidad, una de las aspiraciones burguesas de la educación ${ }^{53}$ o en el de los textos pedagógicos a los que tampoco se nombra ${ }^{54}$.

En cualquier caso y concediendo que se alcanzara la instrucción suficiente, ¿cómo iba a ser posible un cambio de la situación de avasallamiento del Capital sobre el trabajador? En esa equidistancia que se mantiene entre uno y otro, podía haber más oportunidades para mejorar su situación, inclusive asociándose como ellos alentaban, pero

\footnotetext{
${ }^{50}$ En un libro de lectura a fines de siglo, narraba un padre a sus hijos: "Si alguno merece el título de bienhechor de la humanidad, es el maestro de primera enseñanza, humilde sacerdote de la educación, que por un módico sueldo despierta la dormida inteligencia de los niños de corta edad, pues pone en sus labios las primeras oraciones, dirige sus sentimientos, y, empezando por darles a conocer el abecedario y las diferentes articulaciones que con las letras se forman, les enseña el maravilloso arte de la lectura, base de todos los conocimientos, y el no menos preciso de la escritura, por medio de la cual le pone en relación con el resto de la humanidad". Pilar Pascual de San Juan, Escenas de familia. Continuación de "Flora” (Barcelona: Faustino Paluzie, 1895), 206-207. De esta escritora sabemos de sus numerosos libros para niños y niñas de fines del siglo XIX y principios del XX.

${ }^{51}$ Destaquemos lo que atañe a los factores de influencia inmediata: Falta de recursos suficientes, la sobreabundancia de analfabetos, la pobreza en los municipios encargados de asegurar la enseñanza primaria en la escuela, etc.

${ }^{52}$ Una abundante bibliografía editada por la Comisión (Memoria que acerca del estado de las clases obreras de la provincia de Granada (Granada: Ventura Sabatel, 1884); Contestaciones al interrogatorio formulado sobre la limitación de las horas de trabajo (Madrid: Minuesa de los Ríos, 1891); Comisión para el estudio de las cuestiones que interesan a la mejora o bienestar de las clases obreras (Madrid: J. Ducazal, 1884) y sobre todo la que se extiende a partir de 1900 publicada por el Instituto (Preparación al proyecto de Ley regulando la jornada de trabajo de las personas empleadas en los establecimientos mercantiles (Madrid: Suc. Minuesa de los Ríos, 1913); Proyecto de reforma de la Ley de Accidentes del Trabajo de 30 de enero de 1900 (Madrid, Suc. Minuesa de los Ríos, 1908).

${ }^{53}$ Sobre la urbanidad véase Carmen Benso Calvo, "La enseñanza de la urbanidad o de "niño educado" en el siglo XIX", en El libro escolar. Reflejo de intenciones políticas o influencias pedagógicas, Alejandro Tiana Ferrer (Madrid, 1996).

${ }^{54}$ Hay que señalar que los libros de Pedagogía eran escasos, malos y caros. Uno de los más conocidos autores, fue Saturnino Calleja que editó numerosas obras basadas en las más modernas tendencias pedagógicas europeas, haciéndolos atrayentes, insertando numerosos grabados e ilustraciones y vendiéndolos a ayuntamientos pobres con precios muy baratos. Para los antecedentes antes de la Restauración, véase L. Vega Gil, Moderantismo y educación en España. Estudios en torno a la Ley Moyano (Zamora: Instituto Florián de Ocampo, 1995). Sobre la evolución de la escuela, véase Agustín Escolano Benito, La educación en la España contemporánea. Política evolutiva, escolarización y cultura pedagógica (Madrid: Biblioteca Nueva, 2002). Juana García Romero, Acerca de la educación del siglo XIX europea (Madrid: Utopía, 2009). Para una visión general y sobre todo para la época presente, M. de Puelles Benítez, Política y educación en la España contemporánea (Madrid: UAM, edición 2009).
} 
los elementos fundamentales de una estructura oligárquica capitalista, con todos sus fallos, seguiría existiendo. Confiaban en que las mismas clases acomodadas, las explotadoras, si eran ilustradas cambiarían su proceder reprimiendo su ambición en favor de los explotados. Idea muy de acuerdo con los postulados masónicos del control del hombre a través de su esfuerzo personal, mostrando con ello una confianza ilimitada en esta solución. Y un detalle a tener en cuenta: Aunque reconoce tácitamente los antagonismos de clase, no acude en ningún momento a la expresión de ricos y pobres.

Los masones del Alto Organismo como hemos apuntado en el párrafo anterior, partían de un discurso utópico, transformador de la sociedad, que equivalía a su regeneración pacífica. En todo caso se trataba de un regeneracionismo monotemático, es decir, reforma, entendida como una evolución progresiva cuya meta cambiaba a medida que ascendía a grados más altos el progreso humano ${ }^{55}$. Inclusive la Masonería en su vertiente más a la izquierda como el caso que estudiamos aquí al igual que el pensamiento liberal del momento, tiende a un reformismo que no aborda las cuestiones complejas, como las relaciones entre Capital y Trabajo, éstas que no admitían remedios ni recetas milagreras ${ }^{56}$.

Por último, indicar que el discurso masónico se mantiene en una realidad que, a prescindir del sentimiento político por el republicanismo ${ }^{57}$, acepta las condiciones básicas de la estructura social imperante cuyos remedios se plantean como ya mencionado, desde una perspectiva de perfeccionamiento moral del individuo y por ende, de la sociedad, para alcanzar la armonía social, repudiando los cambios revolucionarios violentos colectivos. De ahí la importancia concedida a la educación del individuo pero haciendo abstracción de los factores estructurales que hacían posible aquellos fallos del sistema ${ }^{58}$. Por el momento todos estos datos son reveladores de una estructura mental que nos lleva a afirmar que la ideología manifestada es exponente de una mentalidad típica burguesa decimonónica, mayoritaria en las capas altas y medias de la población.

Con este breve estudio que hemos pergeñado, colocamos una pieza más en la construcción y enriquecimiento de ese mundo de las mentalidades que nos puede ayudar a comprender mejor los acontecimientos históricos y la dinámica social del siglo XIX.

\footnotetext{
${ }^{55}$ En favor de este progreso se situaban las obras de caridad, Hospitales Asilo, Escuelas laicas, Sociedades de ayuda mutua, Montepíos, etc. Para una visión del progreso a fines del siglo XIX, véase Eric Storm, $L a$ perspectiva del progreso. Pensamiento politico en la España del cambio de siglo (1890-1914) (Madrid: Biblioteca Nueva, 2001).

${ }^{56}$ Esta es la opinión del Boletín a esta fecha. Es evidente que su posición se hará más extrema a medida que nos aproximemos al final del siglo.

${ }^{57}$ Sustenta un postulado fundamental: la repulsa global al sistema monárquico. El republicanismo muy dividido, a pesar del fracaso de las uniones republicanas, logra un resurgimiento que triunfará en las elecciones de mayo de 1892, en Madrid y en ocho capitales de provincia.

${ }^{58}$ Descendiendo al plano práctico, más que sostener escuelas propias, la Masonería se dedicó a colaborar con grupos librepensadores y republicanos en la defensa y puesta en marcha de escuelas laicas y racionalistas.
} 


\section{Fuentes}

Boletín de Procedimientos del Gran Oriente Ibérico o Gran Logia Simbólica Española del Rito Primitivo y Oriental de Memphis y Mizraím (1889-1898).

\section{Bibliografía}

Aguirre, María Esther. La escuela primaria (1780-1890). Madrid: Utopía, 2012

Benso Calvo, Carmen. "La enseñanza de la urbanidad o de "niño educado" en el siglo XIX". En El libro escolar. Reflejo de intenciones políticas o influencias pedagógicas. Editado por Alejandro Tiana Ferrer. Madrid, 1996.

De Puelles Benitez, M. Política y educación en la España contemporánea. Madrid: UNED, 2010

Enríquez del Árbol, Eduardo. "Crisis y belicismo: Una perspectiva ideológica de la Masonería española en torno al, 98”. En La Masonería en la crisis colonial del 98. Coordinado por José Antonio Ferrer Benimeli. Zaragoza: Ministerio de Educación y Ciencia, 1999.

Enríquez del Árbol, Eduardo. “Al filo de un centenario: El último Gran Oriente Hispano del siglo XIX: la Gran Logia Simbólica Española del Rito Primitivo y Oriental de Memphis y Mizraim (1889-1989)". En Masonería, Revolución y Reacción. Coordinado por José Antonio Ferrer Benimeli. Alicante: Diputación Provincial, Instituto Gil Albert, 1990.

Enríquez del Árbol, Eduardo. "La prensa masónica en la Andalucía del siglo XIX: Sus orígenes sevillanos: La Fraternidad y El Ramo de Acacia (1870-1873)”. Andalucía Contemporánea III (1996).

Enríquez del Árbol, Eduardo. "La prensa masónica en la Andalucía del siglo XIX: Una aproximación a los orígenes gaditanos". Trocadero 3 (1991).

Enríquez del Árbol, Eduardo. La cuestión romana en el diario madrileño El Pensamiento Español de 1870. Madrid: Fundación Universitaria Española, 1987.

Escolano Benito, Agustín: La educación en la España contemporánea. Política evolutiva, escolarización y cultura pedagógica. Madrid: Biblioteca Nueva, 2002

Fernández Fernández, Pedro Víctor: "La cuestión social en las publicaciones masónicas españolas”. En Masonería española entre Europa y América. Coordinado por José Antonio Ferrer Benimeli. Zaragoza: Gobierno de Aragón, 1995.

Ferrer Benimeli, José Antonio. "La Masonería española y la cuestión social”. Estudios de Historia Social 40-41 (1987).

Frau, L. y R. Arus. Diccionario Enciclopédico de la Masonería, Valle de México, 1976, Tomo III

García Romero, Juana: Acerca de la educación del siglo XIX europea. Madrid: Utopía, 2009. 
Ortiz Villalba, J. "Masonería y cuestión social en la Córdoba del último tercio del siglo XIX”. En La Masonería en la España del siglo XIX. Coordinado por José Antonio Ferrer Benimeli. Valladolid: Junta de Castilla y León, 1987.

Sanllorente Barragan, F. "Anticlericalismo, pacifismo y cuestión social en las logias del Gran Oriente Español”. En La Masonería española y la crisis del 98. Coordinado por José Antonio Ferrer Benimeli. Zaragoza: CEHME, 1999.

Storm, Eric. La perspectiva del progreso. Pensamiento político en la España del cambio de siglo (1890-1914). Madrid: Biblioteca Nueva, 2001.

Tuñon de Lara, M. Medio siglo de cultura española. Madrid: Tecnos, 1970.

Vega Gil, L. Moderantismo y educación en España. Estudios en torno a la Ley Moyano. Zamora: Instituto Florián de Ocampo, 1995.

Vergara, R. "Relaciones e influencia entre la Masonería y la Institución Libre de Enseñanza: El caso de Rafael Altamira”. En La Masonería en la España del siglo $X X$. Coordinado por José Antonio Ferrer Benimeli. Toledo: Universidad Castilla la Mancha, 1996. 